\title{
THE LATER PRIVY COUNCIL AND A DISTINCTIVE NEW ZEALAND JURISPRUDENCE: CURB OR SPUR?
}

\author{
David Baragwanath*
}

The Privy Council was New Zealand's final court from 1840 until 2004. Its influence was largely benign, correcting errors of principle and, both in the early days and very recently, affording protection to Māori. But despite important exceptions, its failure to fully acknowledge New Zealand's independent identity, seen most importantly in its refusal during five of its final six decades to acknowledge the true legal effect of the Treaty of Waitangi, delayed the evolution of a distinctive New Zealand jurisprudence.

\section{INTRODUCTION}

George Barton was a gracious opponent who combined great courtesy with formidable intelligence and a deep understanding of law, qualities which he used to protect the weak. ${ }^{1}$ His most famous victory is perhaps Lesa $v$ Attorney-General, ${ }^{2}$ in which the court of one sovereign State, the United Kingdom, held definitively that a citizen of a second sovereign State, Samoa, was also a citizen of a third sovereign State, New Zealand. ${ }^{3}$ This is one of many Privy Council cases that he

* Sir David Baragwanath KNZM QC; President of the Special Tribunal for Lebanon; presiding judge of the Court of Appeal of Samoa and Overseas Bencher of the Inner Temple; formerly of the New Zealand bar, President of the New Zealand Law Commission and member of the Court of Appeal of New Zealand.

1 My own special memory is of his celebrated oral application to Greig $\mathrm{J}$ in New Zealand Māori Council v Attorney-General HC Wellington CP 553/87, 30 September 1987 for the interim declaration that stopped the creation of further fishing quotas. This application was made on instructions received from Martin Dawson one evening in a barber's chair, which was pivotal in the recognition of Māori fishing rights. The judgment appears as a schedule to Waitangi Tribunal The Muriwhenua Fisheries Claim (Wai 22, 1988).

2 Lesa v Attorney-General [1983] 2 AC 20 (PC). Aside from perhaps Fitzgerald v Muldoon [1976] 2 NZLR 615 (SC Wellington).

3 As a judge in the second State and a former judge in the third I make no comment on the decision and the Citizenship (Western Samoa) Act 1982 which reversed it, giving effect to the Protocol done at Apia on 21 August 1982 to the Treaty of Friendship between the Government of New Zealand and the Government of Western Samoa done at Apia on 1 August 1962 (see the long title of the Citizenship (Western Samoa) Act 1982). 
argued with distinction. Both the recipient of a $\mathrm{PhD}$ from Cambridge, learned in English law, and a New Zealand jurist and silk, he would have relished the present topic.

\section{HOW COULD THE PRIVY COUNCIL BE EXPECTED TO ENCOURAGE A DISTINCT NEW ZEALAND JURISPRUDENCE?}

Use of the law to subdue recalcitrant indigènes was always an important technique of the colonising power. Francesco de Vittoria, even while formulating the profoundly important principle of colonial law that usages of the indigenous people should be recognised as laws of the colonial regime, created an exception for those who resisted Spanish proselytising which thereby demolished the culture. ${ }^{4}$ His was an early example of the 'my culture first' policy which was applied quite generally by colonial rulers and judges. James Stephen, the great Colonial Office Under-secretary who oversaw much of the colonisation of Canada, Australia and New Zealand, ultimately acknowledged that he always took care to ensure that the interests of the United Kingdom came first. ${ }^{5}$ Quite recently in $R$ (Bancoult) $v$ Secretary of State for Foreign and Colonial Affairs, ${ }^{6} \mathrm{a}$ majority of the House of Lords (reversing the opinion of five judges below) sustained a Colonial Office Order in Council which it acknowledged was made "in callous disregard for the ... interests" of the Chagossians of the British Indian Ocean Territory who had been expelled from their homes to make way for an air base at Diego del Garcia. ${ }^{7}$ Although the Order in Council was rationally unsustainable, preventing the Chagossians' return to home islands far removed from the air base, Lord Hoffmann held: 8

Her Majesty [in Council] exercises her powers of prerogative legislation for a non-self-governing colony on the advice of her ministers in the United Kingdom and will act in the interests of her undivided realm, including both the United Kingdom and the colony

$\cdots$

Her Majesty in Council is therefore entitled to legislate for a colony in the interests of the United Kingdom. No doubt she is also required to take into account the interests of the colony ... but there

4 Francisco de Vitoria De Indis et de Iure Belli Reflectiones (1557) reprinted in Ernerst Nys (ed) Classics of International Law (Carnegie Institution of Washington, Washington DC, 1917).

5 James Stephen "Colonisation as a Branch of Social Economy" (1858) reproduced as an appendix to Paul Knaplund James Stephen and the British Colonial System 1813-1847 (University of Wisconsin Press, Madison, 1953).

$6 \quad R$ (Bancoult) v Secretary of State for Foreign and Colonial Affairs [2008] UKHL 61, [2009] 1 AC 453.

7 At $[10]$.

8 At [47] and [49]. 
seems to me no doubt that in the event of a conflict she is entitled, on the advice of her United Kingdom ministers, to prefer the interests of the United Kingdom.

The argument that, as British citizens, the Chagossians were entitled to an Englishman's constitutional protection of his home, adopted by Lords Bingham and Mance in dissent, was rejected.

So, with such a 'my culture first' attitude, how could the Privy Council be expected to encourage a distinct New Zealand jurisprudence? The reality is that, for the most part, it has done so with principled distinction, both before and since New Zealand became self-governing. Where there is no conflict of interest or difference in culture, it has proved that the ablest judges in the United Kingdom, with experience of human difference first within the Empire and Commonwealth and more recently in Europe, would enrich New Zealand jurisprudence. They did so, not least by an understanding of vive la différence derived from their unparalleled exposure to customs and values of colonial States across the red-painted globe and beyond. Hence, for instance, the Privy Council decisions during the colonial era holding that New Zealand judges had erred in preferring the interests of the colonists to the rights of Māori. Among them was the forthright judgment of Lord Macnaghten in Wallis $v$ Solicitor-General which led to the Protest of Bench and Bar recorded at the end of the New Zealand Privy Council Cases volume. ${ }^{9}$

These decisions brought out, ironically enough, the failure of New Zealand judges to create a distinctive New Zealand jurisprudence protecting its indigenous people, a deficiency evidencing the 'my culture first' attitude which the Privy Council usually proceeded to rectify.

But in Hoani Te Heuheu Tukino $v$ The Aotea District Land Board, until recently both the most important decision on the status of the Treaty of Waitangi and regarded as authoritative, the argument of Denning KC for the respondent Board was accepted in the following terms: ${ }^{10}$

Under Art I there had been a complete cession of all the rights and powers of sovereignty of the Chiefs.

It is well settled that any rights purporting to be conferred by such a treaty of cession cannot be enforced in the Courts, except in so far as they have been incorporated in the municipal law. The principle laid down in a series of decisions was summarized by Lord Dunedin in delivering the judgment of this Board in the Gwalior case, Vajesingji Joravarsingji v Secretary of State for India in these words:

When a territory is acquired by a sovereign state for the first time, that is an act of state. It matters not how the acquisition has been brought about. It may be by conquest, it may be by cession following on treaty, and it may be by occupation of territory hitherto unoccupied by a

9 Wallis v Solicitor-General [1903] AC 173 (PC); "Protest of the Bench and Bar, April 25, 1903" [18401932] NZPCC Appendix 730. See also Nireaha Tamaki v Baker [1901] AC 561 (PC).

10 Hoani Te Heuheu Tukino v the Aotea District Māori Land Board [1941] AC 308 (PC) at 324-325 (emphasis added and references omitted). 
recognized ruler. In all cases the result is the same. Any inhabitant of the territory can make good in the municipal courts established by the new sovereign only such rights as that sovereign has, through his officers, recognized. Such rights as he had under the rule of predecessors avail him nothing. Nay more, even if in a treaty of cession it is stipulated that certain inhabitants should enjoy certain rights, that does not give a title to those inhabitants to enforce these stipulations in the municipal courts. The right to enforce remains only with the high contracting parties. This is made quite clear by Lord Atkinson when, citing the Pongoland case of Cook $v$ Sprigg, he says, "It was held that the annexation of territory made an act of state and that any obligation assured under the treaty with the ceding state either to the sovereign or to the individuals is not one which the municipal courts are authorized to enforce."

So far as the appellant invokes the assistance of the Court, it is clear that he cannot rest his claim on the Treaty of Waitangi, and that he must refer the Court to some statutory recognition of the right claimed by him.

But why? Why should not the new colonial law recognise rights solemnly promised by the other "high contracting party"? Especially when the other high contracting party - the sovereign Māori chiefs - signed away their authority on the strength of the promises of the other party, and there is no longer any Māori "high contracting party" to enforce the transaction?

Indeed the colonial law of which Vittoria wrote should, if duly applied, protect such rights by giving effect to customary practices even without a treaty. ${ }^{11}$ Why the judges should develop the common law so as to benefit people like themselves, and why it could not come to the aid of the Māori claimants, was never discussed.

The time is now long overdue to recognise that. To say the Treaty rights cannot be enforced by the domestic courts is anachronistic. By what other lawful means can the successors of the Māori signatories, recognised by three statutes of the United Kingdom as sovereign peoples, secure performance of the Treaty promises? Certainly the Treaty of Waitangi is not a statute and enforceable as such. But nor is it a legal nothing. Nowadays, as New Zealand's leading international lawyer wrote in New Zealand Airline Pilots' Association Inc v Attorney-General: ${ }^{12}$

We begin with the presumption of statutory interpretation that so far as its language allows legislation should be read in a way which is consistent with New Zealand's international obligations.

11 As Lord Denning showed in a Privy Council appeal from West Africa Oyekan v Adele [1957] 1 WLR 876 (PC).

12 New Zealand Airline Pilots' Association Inc v Attorney-General [1997] 3 NZLR 269 (CA) at 289 per Keith $\mathrm{J}$. 
And as the same judge showed in Sellers $v$ Maritime Safety Inspector, ${ }^{13}$ very clear statutory language is required to have such an unprincipled effect which would put New Zealand in breach of international law. How much more must these principles apply when what is at stake is no less than the conditions on which legitimacy was granted to the legal system which sits in judgment upon them? Yet the paralysing effect of Privy Council authority has kept New Zealand in a colonial time warp which it will now be for the Supreme Court to cut through.

This article is limited in the main to some decisions in the period of my experience of the Privy Council, essentially in the four decades from 1966 until the Supreme Court of New Zealand began its work in 2004. By then New Zealand was no longer a colony so the de haut en bas ratio of Bancoult should no longer apply. But care is needed to consider whether any other considerations, notably unfamiliarity with New Zealand conditions, have distracted the Privy Council from making an optimal contribution to a distinctive New Zealand jurisprudence. ${ }^{14}$

There are of course different types of distinctiveness. I take the topic to be of the virtuous kind, where distinctiveness is a good thing. But other forms of distinctiveness warrant mention as well.

\section{FRAZER v WALKER}

In the case of Frazer $v$ Walker, had Sir Garfield Barwick, Chief Justice of Australia, not sat, what would have happened? ${ }^{15}$ The thought is intriguing. Mr and Mrs Frazer were registered proprietors of land. Mrs Frazer signed her own name and forged her husband's signature to a memorandum of mortgage in favour of a mortgagee, Mr Radomski, who having made the loan, registered his mortgage securing it. At mortgagee sale Mr Walker was the purchaser and he registered the memorandum of transfer from Radomski. Whose title should prevail? At first instance Richmond $\mathrm{J}$ held in favour of Radomski and, a fortiori, for Walker. ${ }^{16}$ The Court of Appeal allowed Frazer's appeal against Radomski but dismissed it against Walker.

The four English Law Lords - Dilhorne, Denning, ${ }^{17}$ Wilberforce and Hodgson - and Sir Garfield Barwick were faced with the conundrum which had divided the full Court of Appeal in Boyd v Mayor of Wellington which, with Salmond $\mathrm{J}$ in dissent, accepted that a proprietor's land

13 Sellers v Maritime Safety Inspector [1999] 2 NZLR 44 (CA).

14 Of course the work of the New Zealand judiciary, including its own attitude to indigenous cases, will require appraisal, but requires greater objectivity than I can provide.

15 Frazer v Walker [1967] 1 AC 569 (PC).

16 He was present in London at the time of the appeal, keeping proper distance from the proceedings. The vindication by the Privy Council of his intellect and judgment will not have harmed his prospects of promotion to presidency of the Court of Appeal.

17 Who in recognition of the background of all counsel wore an Auckland Law School tie. 
could be lost merely by registration under the Torrens land transfer legislation of an inconsistent title. $^{18}$

Section 62 of the Land Transfer Act 1952 provided the terse exception to the finality of registration: "except in the case of fraud". Temm and Barker for Mr Frazer argued that registration of a document obtained by the fraud of Mrs Frazer triggered the exception, which applied to both the Radomski and the Walker titles. The Law Lords were very reluctant to deprive an innocent property owner of the title which a fraudster had sought to remove by securing registration of another innocent party. The debate between Speight (for Radomski) and Lord Wilberforce, whose reluctance to upset apple carts would be seen in his later dissent in Mangin v Commissioner of Inland Revenue, ${ }^{19}$ was titanic.

Speight submitted the Land Transfer Act to close analysis, arguing that its core principle was $\mathrm{s}$ 62 by which registration was everything, save in the case of fraud by the title-holder. Other provisions, such as s 82, which empowered the Registrar to rectify the register, were subordinate. It followed that Radomski's title as mortgagee prevailed over that of Mr Frazer, whose remedy was against the statutory compensation fund.

The Law Lords' acceptance of Speight's argument entailed a rejection of the fundamental tenet of English land law that no unlawful or, in itself, invalid transaction can rob an Englishman of his castle. Australasian jurisprudence, at the heart of our land law, was put on a clear and principled basis which includes compensation provisions for one whose land is lost as a result. ${ }^{20}$ Whether Barwick CJ persuaded his four English colleagues that they really need not concern themselves with the consequences of what Australasian legislatures had done to the notion of one's home as one's castle, has not been disclosed.

But without doubt the Privy Council ensured the distinctiveness of New Zealand law.

\section{INVERCARGILL CITY COUNCIL V HAMLIN}

The leaky building cases brought out a clear distinction between United Kingdom and New Zealand conditions at two levels: in the first instance the distinction was at least ostensibly factual, but ultimately it was treated as legal without any need for factual difference. The English courts decided that buildings were to be characterised as assets no different from any other investment. And they declined to apply to such assets any principle that liability arises at public law for careless failure to discharge a local authority's obligation to inspect the building in the course of construction. In Invercargill City Council v Hamlin the Privy Council permitted the New Zealand courts to go their own different way, and so did not obstruct the development of a distinctive

18 Boyd v Mayor of Wellington [1924] NZLR 1174 (CA).

19 Mangin v Commissioner of Inland Revenue [1971] AC 739, [1971] NZLR 591 (PC).

20 Land Transfer Act 1952, s 172. 
jurisprudence. ${ }^{21}$ But the creation of that distinctive jurisprudence was driven by New Zealand judges.

The judgment of the Court of Appeal in Hamlin reveals the shadow cast by the Privy Council over the development of a distinctive New Zealand jurisprudence. The Court was at pains to spell out why New Zealand conditions were said to be different, so as to escape the rule stated by the Privy Council's alter ego, the House of Lords, in Murphy v Brentwood District Council. ${ }^{22}$ So in the Sunset Terraces case we were presented with a powerful and logical argument by the appellant Council that Hamlin was to be treated as exceptional and should be confined to the domestic dwelling there in issue, rather than extended to embrace apartments in a large block. ${ }^{23}$ By this stage we were relieved of the prospect of any appeal to Downing Street and were able, without distraction, to consider what New Zealand conditions required. We departed from the notion that a dwelling is to be characterised simply as another investment. Rather, we sought to identify where habitation ranks in the scale of New Zealand values. We held that it should be treated as different in kind from the assets considered in such cases as Cattle $v$ Stockton Waterworks Co for which the common law has long declined protection from economic loss caused merely by carelessness. ${ }^{24}$ The result was a flat rejection of the English rule stated in Murphy.

I raised in support of that conclusion the further option of reviewing the narrow constraints imposed on tort liability of councils by the majority judgment in Stovin $v$ Wise. ${ }^{25}$ Examination of available materials recounting the experience in France and Germany suggested that the English courts had assumed, without evidence, the need for council protection and that there could well be grounds for reviewing how New Zealand law should approach the topic. In Stovin Lord Nicholls, dissenting, pointed out that there was an obvious risk which the Norfolk Council had the power to remove at a cost of $£ 1000$. But although the Council could easily have removed the risk, it did nothing. Lord Nicholls did not consider that the discredited decision in East Suffolk Rivers Catchment Board $v$ Kent provided sufficient reason to withhold liability. ${ }^{26}$

New Zealand has gained, and continues to gain, great advantage from our lineal descent from the United Kingdom. But, having argued publicly first for retention of Privy Council appeals and later for their abolition, I have no doubt that we were right, although belated, in severing the formal

21 Invercargill City Council v Hamlin [1996] 1 NZLR 513 (PC).

22 Murphy v Brentwood District Council [1991] AC 398 (HL).

23 North Shore City Council v Body Corporate 188529 [2010] NZCA 64, [2010] 3 NZLR 486 [known as Sunset Terraces]; North Shore City Council v Body Corporate 188529 [2010] NZSC 158, [2011] 2 NZLR 289.

24 Cattle v Stockton Waterworks Co (1875) LR 10 QB 453.

25 Stovin $v$ Wise [1996] AC 923 (HL).

26 East Suffolk Rivers Catchment Board v Kent [1941] AC 74 (HL). 
link, while retaining the close ties that are such strength to our jurisprudence. For repeatedly we have been saved by the Privy Council's intervention from a distinctiveness that is undesirable. ${ }^{27}$ That should of course be seen in context and not overstated. As Newton modestly put it, "If I have seen farther it is by standing on the shoulders of giants." 28

Reading on the British and Irish Legal Information Institute website all the New Zealand Privy Council cases from 1966 brought to mind how the case would have ended had we then had our third New Zealand tier. An appellate court's starting point is the judgment under appeal coupled with submissions as to where it is wrong and why. Most appeals were dismissed, even though a substantial number were allowed. What is to be said of New Zealand distinctiveness in that process? There are three very different classes of case where the appeal is allowed:

(1) the decision under appeal is wrong in law;

(2) it is a legitimate choice which the appellate court elects not to prefer; and/or

(3) the appellate court is wrong.

There is also a fourth category where the final court, while dismissing the appeal, improves the jurisprudence.

In relation to "wrong in law", I venture a personal opinion of what some standard-setting judges, whose company George has now joined, would have made of it. They include the Australian Owen Dixon, the Canadian Bertha Wilson, the American Roger Traynor and the Englishman Tom Bingham. After half a century of acclimatisation to the law of England, where our final appeals were determined, and with close continuing links to those who practise it, I acknowledge some general predilection for English law. My position is to treat it, generally, as continuing to state general principles of law which are as valuable for general application in New Zealand as in other like societies, there often being no relevant difference of values. On occasion the Privy Council has performed the service of bringing us back to what I consider true principle.

\section{A Class 1: The Court of Appeal was in error}

Cases of Class 1 are inevitable from time to time in a court as busy as was the New Zealand Court of Appeal in the 40 years under review. Take Downsview Nominees Ltd v First City Corporation $L t d .{ }^{29}$ A very strong Court of Appeal had allowed an appeal and declined relief against the respondent who had bought a first debenture and was held to have obstructed a second debenture-holder in the realisation of assets to meet its debt. The Court characterised the case as

27 See text at fns 9, 15, 29, 30, 32, 36, 40 and 43.

28 Letter from Isaac Newtown to Robert Hook (5 February 1676) in Stephen Hawking On the Shoulders of Giants (Running Press, Pennsylvania, 2002) at 725.

29 Downsview Nominees Ltd v First City Corporation Ltd [1993] AC 295 (PC). 
lying within the tort of negligence and held there was no breach of duty. The Privy Council allowed the further appeal, with inexorable reasoning that the relevant principles actually were those of equity. Had the relevant arguments been advanced to the Court of Appeal it would undoubtedly have reached the same conclusion.

A second example is $B v$ Auckland District Law Society where the majority in the Court of Appeal had not recognised that legal professional privilege is a fundamental principle with which legislation is presumed to conform. ${ }^{30}$ The Privy Council applied that principle. It had received effect when stated with clarity in the earlier New Zealand full Court of Appeal judgment in Commissioner of Inland Revenue $v$ West-Walker. ${ }^{31}$

A third example is Attorney-General of Hong Kong $v$ Reid. ${ }^{32}$ The respondent, a New Zealand prosecutor in Hong Kong, accepted bribes to secure unjustified acquittals. The Hong Kong Government sought to enforce against Reid's assets in New Zealand (said to derive from the bribes) a judgment against him for their amount. The Court of Appeal conceived itself to be bound to follow the long-standing English Court of Appeal judgment in Lister \& Co v Stubbs, ${ }^{33}$ that such claim did not lie. The Privy Council stated the true principle: ${ }^{34}$

The decision in Lister \& Co $v$ Stubbs is not consistent with the principles that a fiduciary must not be allowed to benefit from his own breach of duty, that the fiduciary should account for the bribe as soon as he receives it and that equity regards as done that which ought to be done. From these principles it would appear to follow that the bribe and the property from time to time representing the bribe are held on a constructive trust for the person injured. A fiduciary remains personally liable for the amount of the bribe if, in the event, the value of the property then recovered by the injured person proved to be less than that amount.

The Privy Council observed that since the Court of Appeal was not bound by any decision of the Court of Appeal of England: ${ }^{35}$

[T] merits and to depart from it if the authority is considered to be wrong.

In adding a fourth case to the present category, Kuwait Asia Bank EC v NML Nominees Ltd, I declare a vested interest. ${ }^{36}$ But I am comforted by the opinion of Professor Watts that the Privy

30 B v Auckland District Law Society [2003] UKPC 38, [2004] 1 NZLR 326.

31 Commissioner of Inland Revenue v West-Walker [1954] NZLR 191 (CA).

32 Attorney General of Hong Kong v Reid [1994] 1 AC 324 (PC).

33 Lister \& Co v Stubbs (1890) 45 Ch D 1 (CA).

34 Attorney General of Hong Kong v Reid, above n 32 at 336-F.

35 At 338-G. 
Council, in rejecting the argument that nominee directors' negligence in operating a company imposes vicarious liability on their appointor, was correct in principle. ${ }^{37}$ The case reminds me of another, from 1960, Lee $v$ Lee's Air Farming Ltd, where the Court of Appeal had held that a governing director of a company could not concurrently be its servant and therefore his widow was not entitled to compensation under the Workers Compensation Act $1956 .{ }^{38}$ The appeal was allowed on the principled basis that the company was an entity separate in law from its directors and members. As in its famous precursor, Saloman $v$ Saloman \& $C o,{ }^{39}$ the final court severed the human link between the company and its human elements, giving effect to the legislative policy that a company is a distinct legal entity.

The fifth and most striking recent example of error is Taito $v R .^{40}$ There, each appellant had a statutory right to appeal to the Court of Appeal without leave from decisions of lower courts. Each lodged notice of appeal against his conviction but none could afford legal representation. Each applied for legal aid. Although in legal aid applications the decision was in law that of the registrar, not of a judge, their applications were declined on paper by three judges of the Court of Appeal who never met to discuss the merits. When, as was common, no submissions in support of the appeal were filed, the Court of Appeal routinely dismissed the appeal without examination of the merits and without reasons. The appellants were declined leave to be present in court. Nor were they provided with transcripts of the evidence which was received by the judges. The members of the Court of Appeal took the view that, if legal aid had been declined, the case had no reasonable prospects of success. The Privy Council held that such procedures were radically flawed. Each appellant had been deprived of the oral hearing which was his right. The Privy Council further concluded: 41

[T] he practice of the Court of Appeal distinguished in effect between rich and poor inasmuch as a rich appellant, who was represented, always received an oral hearing before the Court of Appeal whereas the poor appellant, who was denied legal aid on paper, was never accorded such a right. It has to be said that in the result the system operated arbitrarily. Certainly, it was contrary to fundamental conceptions of fairness and justice. The appellants were entitled to the observance of the principles of natural justice or

36 Kuwait Asia Bank EC v NML Nominees Ltd [1991] 1 AC 187 (PC). Having been run unsuccessfully before six New Zealand judges, the argument was advanced more persuasively by counsel who took over the case when I had a conflict of fixtures.

37 Peter Watts "Company Law and the Court of Appeal 1958-2008" in Rick Bigwood (ed) The Permanent New Zealand Court of Appeal: Essays on the first 50 years (Hart, Oxford, 2009) 212 at 245-249.

38 Lee v Lee's Air Farming Ltd [1961] AC 12 (PC).

39 Saloman v Saloman \& Co [1897] AC 22 (HL).

40 Taito v R [2002] UKPC 15, [2003] 3 NZLR 577.

41 At [20] (citations omitted). 
fairness. In the landmark case Ridge $v$ Baldwin Lord Morris of Borth-y-Gest observed about the principles of natural justice: "here is something basic to our system: the importance of upholding it far transcends the significance of any particular case".

The problem was squarely faced by the Court of Appeal in $R v$ Smith, ${ }^{42}$ where it accepted the need to rectify the errors and put in place effective systems to ensure a just reconsideration.

It can be powerfully argued that $O^{\prime}$ Connor $v$ Hart is yet another example of this class. ${ }^{43}$ Should a party who lacks mental capacity be bound by an ostensible contract with a second party acting in good faith who is unaware of the incapacity? The Privy Council, reversing both New Zealand courts on the point, and also the law of Scotland, said yes: ${ }^{44}$

It seems to their Lordships quite illogical to suppose that the courts of common law would have held that a person of unsound mind, whose affliction was not apparent, was nevertheless free of his bargain if a contractual imbalance could be demonstrated which would not have availed him in equity.

Such an approach accords with a purist view that contract law must always be based on a general objective test. It might be suggested that, since the point of law turned on a choice of competing values, there was actually no lack of logic in the opposing opinion, so the case can be treated as falling into the next class. But such a conclusion would make for such uncertainty that I prefer the sterner answer.

\section{B Class 2: It Could Have Gone Either Way}

An example of Class 2 is Lange $v$ Atkinson. ${ }^{45}$

In August 2000, the New Zealand Law Commission released a report entitled Defaming Politicians: A Response to Lange v Atkinson. ${ }^{46}$ In the Preliminary Paper, the authors challenged a decision of the Court of Appeal as extending over-broadly the defence of qualified privilege to a defamation claim. ${ }^{47}$ In the following sustained passage in its subsequent judgment, the Privy

$42 \quad R v$ Smith [2003] 3 NZLR 617 (CA).

43 O'Connor v Hart [1985] AC 1000 (PC).

44 At 1024-E.

45 Lange v Atkinson [2000] 1 NZLR 257 (PC).

46 Law Commission Defaming Politicians: A Response to Lange v Atkinson (NZLC R64, 2000).

47 Law Commission Defaming Politicians: A Response to Lange v Atkinson (NZLC PP33, 1998) at v. Note also at vi (with citations omitted):

This topic was included in the Commission's programme following the February 1997 first instance decision, our intention being to delay starting work until after the Court of Appeal had delivered judgment. We considered delaying the task even further because of the likelihood of an appeal to the Privy Council (conditional leave was granted on 20 July 1998) but decided against this. It needs to be remembered that since Invercargill City Council $v$ 
Council explicitly acknowledged the options in the context of the clash between protection of reputation and freedom of speech: ${ }^{48}$

[O]ne feature of all the judgments, New Zealand, Australian and English, stands out with conspicuous clarity: the recognition that striking a balance between freedom of expression and protection of reputation calls for a value judgment which depends upon local political and social conditions. These conditions include matters such as the responsibility and vulnerability of the press. In their Lordships' view, subject to one point mentioned later, this feature is determinative of the present appeal. For some years their Lordships' Board has recognised the limitations on its role as an appellate tribunal in cases where the decision depends upon considerations of local public policy. The present case is a prime instance of such a case. As noted by Elias J and the Court of Appeal, different countries have reached different conclusions on the issue arising on this appeal. The courts of New Zealand are much better placed to assess the requirements of the public interest in New Zealand than their Lordships' Board. Accordingly, on this issue the Board does not substitute its own views, if different, for those of the New Zealand Court of Appeal.

This approach has been adopted in cases, such as Invercargill City Council v Hamlin where a line of New Zealand authorities stretched over some years. But the existence of a line of authority is not essential. In principle, the approach is equally applicable where the case under appeal has no local ancestry. An instance of this arose earlier this year, in $W v W$. The present case is of the latter character. $\cdots$

[D]ue to the accident of timing, when considering this issue the English courts have had the benefit of the New Zealand and Australian Lange decisions, but the New Zealand courts have not had the benefit of the English decisions in Reynolds. For the reason already given, the English case law is by no means determinative of the issue arising in the present case. But an appraisal of the English case law is an important part of the background against which the courts in New Zealand are assessing the best way forward on this important and difficult point of the common law. This is not surprising. Even on issues of local public policy, every jurisdiction can benefit from examinations of an issue undertaken by others. Interaction between the jurisdictions can help to clarify and refine the issues and the available options, without prejudicing national autonomy.

Their Lordships consider that the advent of the decision of the House of Lords in Reynolds is a matter the New Zealand Court of Appeal would wish to have the opportunity to take into account when formulating the common law of New Zealand on this issue. In order to achieve this end, and in this

Hamlin, New Zealand decisions out of line with the common law as settled in other jurisdictions may be left untouched by the Privy Council on the basis that "conditions in New Zealand are different".

48 Lange v Atkinson, above n 45, at 259-263 (citations omitted). 
unusual situation, their Lordships are of the view that the appropriate course is formally to allow this appeal and remit the matter to the Court of Appeal for further hearing.

On further consideration, the Court of Appeal elected to amplify and clarify its earlier decision in the light of this advice. ${ }^{49}$

The recognition by the Privy Council of the fact that social conditions may be different, acknowledging local distinctiveness, is of the greatest value.

\section{Class 3: Appellate Error}

One hesitates before venturing into this territory, the more so when a decision of one's own is relevant to it. But since there are no pending Privy Council tax appeals from New Zealand and there are now leading decisions of the Supreme Court of New Zealand which may be seen as inconsistent with its jurisprudence, I offer the following.

English tax law was long formulated in terms of the Duke of Westminster case, ${ }^{50}$ and Cape Brandy Syndicate v Inland Revenue Commissioners: "One has to look merely at what is clearly said. There is no room for any intendment. There is no equity about a tax." ${ }^{51}$ These cases were cited in Mangin v Commissioner of Inland Revenue where Wilson J had held that a farmer could lawfully mitigate his tax by creating a series of paddocks and separate trusts for each. The Court of Appeal was unimpressed and reversed him. ${ }^{52}$ In the Privy Council the taxpayer's appeal was dismissed by the majority. ${ }^{53}$ Lord Wilberforce dissented, finding that each detail of the trusts had been meticulously put in place, but uncharacteristically losing the wood in the trees.

It became something of a habit of English members of the Privy Council to assume that New Zealand appeals should be determined on an application of the English cases. In Miller $v$ Commissioner of Inland Revenue I considered a rather different approach was required to our tax avoidance provisions. ${ }^{54}$ I argued that the evaluation of whether a taxpayer's conduct, which complied meticulously with every syllable of other parts of the tax legislation, fell foul of the broad tax avoidance provisions, was to be assessed against a standard of propriety.

49 Lange v Atkinson [2000] 3 NZLR 385 (CA) at [21]-[22].

50 Inland Revenue Commissioners v Duke of Westminster [1936] AC 1 (HL).

51 Cape Brandy Syndicate v Inland Revenue Commissioners [1921] 1 KB 64 at 171.

52 Commissioner of Inland Revenue v Mangin [1970] NZLR 222 (CA).

53 Mangin v Commissioner of Inland Revenue [1971] NZLR 591 (PC).

54 Miller v Commissioner of Inland Revenue (1997) 18 NZTC 13,001 (HC) at 13,031. 
Predictably, given the forum and its authorities, Crown counsel did not support this formulation and in due time the judgment in Miller was delivered, stating: 55

This suggests a moral judgment which Their Lordships think is inappropriate and has been consistently repudiated in cases on tax avoidance schemes in England and New Zealand.

Of course it had been consistently repudiated, in cases like the Duke of Westminster's case and Cape Brandy Syndicate. But the whole point of the New Zealand tax avoidance provisions was to escape from them. I considered that Parliament had given the courts the sort of authority conferred on the Environment Court: to evaluate and resolve a competition between legitimate competing interests. Here, these competing interests were the desire of a taxpayer to regulate matters so as to minimise tax, and the desire of Parliament to fund public activities. I saw the case as one of which Jeremy Bentham said: 56

[T] he legislator, who cannot pass judgment in particular cases, will give directions to the tribunal in the form of general rules, and leave them with a certain amount of latitude in order that they may adjust their decisions to special circumstances.

My test was whether the ordinary New Zealander would regard the scheme as proper or improper; in other parlance, whether it was 'over the top'.

I was comforted to read the dissenting judgment of Lords Bingham and Scott in Peterson $v$ Commissioner of Inland Revenue, stating: ${ }^{57}$

[A]s was pointed out by Thomas $\mathrm{J}$ in his dissenting judgment in Commissioner of Inland Revenue $v$ BNZ Investments Ltd the jurisprudential development of those principles in the United Kingdom has little, if any, relevance, to the correct interpretation and application of s 99. It is the legislature, not the judiciary that has provided the counter to tax avoidance. In New Zealand whether the application of s 99 is permissible must be decided as a matter of statutory interpretation.

Since the task is one of evaluating whether the form of attempted mitigation is proper (that is, permitted by law), or improper (that is, seeking to escape one's fair share of the tax burden), I remain attracted both to impropriety as a test and the dissent in Peterson as demonstrating uncharacteristic error of the Privy Council which impeded the distinctiveness of New Zealand law.

55 Miller v Commissioner of Inland Revenue [2001] UKPC 17, [2001] 3 NZLR 316 at [9].

56 Jeremy Bentham Theory of Legislation being Étienne Dumont Principes de Législation and Traités de Législation, Civile et Pénale (CM Atkinson (trans and ed) Oxford University Press, London, 1914) at 62 cited in Chief Executive of the Department of Labour v Yadegary [2008] NZCA 295, [2009] 2 NZLR 495 at [33].

57 Peterson v Commissioner of Inland Revenue [2005] UKPC 5, [2006] 3 NZLR 433 at [58] (citations omitted). 


\section{Class 4: The Appeal is Dismissed but the Jurisprudence Improved}

It is always to be hoped that a final appellate court will clarify and sharpen the jurisprudence of the courts below. Sometimes that can achieve such distinction as to be distinctive. That may be done by sweeping away detritus and restoring golden principle that lies beneath. So in Lewis v Hyde, ${ }^{58}$ the Privy Council returned to the simple test for voidable preference - whether "equality has been defeated" - formulated in 1768 by Lord Mansfield; ${ }^{59}$ another example of how he devised our basic commercial law. Sometimes it is done by synthesising earlier authorities, as by Lord Hoffmann in Meridian Global Funds Management Asia Ltd $v$ Securities Commission in showing how, when human conduct is attributed to a company, one is dealing with a legal fiction; not, in Kant's expression, a "ding an sich". ${ }^{60}$

But such jurisprudence was not distinctly of New Zealand. The decision in New Zealand Māori Council v Attorney-General (TV) is another matter. ${ }^{61}$ The appeal from the Court of Appeal decision, from which the President Lord Cooke dissented, lifted the Treaty jurisprudence of the Court of Appeal to a loftier plain. Underlying the velvet glove of the judgment, which accepted that the Crown's undertakings might not be enforceable in law, was an unmistakable steel fist: ${ }^{62}$

[T] he Solicitor General, subject to the variations necessary due to the passage of time, gave their Lordships an assurance that the proposals made by the Cabinet between the two hearings at first instance would still be adhered to by the Crown if this appeal is dismissed. The judge was entitled to take this assurance into account, as can their Lordships in determining the outcome of this appeal, in assessing the reasonableness of the Crown's conduct. The assurance may not be directly enforceable in law and it has to be considered in the context of Maori fulfilling their responsibilities to take such action as is reasonably available to preserve the language, but this does not mean that it is devoid of legal significance. The assurance once given creates the expectation, or to use the current parlance the "legitimate expectation: that the Crown would act in accordance with the assurance, and if, for no satisfactory reason, the Crown should fail to comply with it, the failure could give rise to a successful challenge on an application for judicial review.

In these circumstances their Lordships can see no grounds for differing from the judge's very careful assessment of the facts and issues. Accordingly, the appeal should be dismissed and their Lordships will humbly so advise Her Majesty.

58 Lewis $v$ Hyde [1998] 1 NZLR 12 (PC).

59 Alderson v Temple (1768) 4 Burr 2235, 98 ER 165 (KB) at 2239.

60 Meridian Global Funds Management Asia Ltd v Securities Commission [1995] 2 AC 500 (PC) at 5.

61 New Zealand Māori Council v Attorney-General (TV) [1994] 1 AC 466 (PC).

62 Ibid at 467-468. 
That failure to comply with an unenforceable undertaking would itself be actionable, may be novel jurisprudence. But it was effective. The aftermath of the adequately funded and wellpresented Māori programme entailed an appropriate governmental response, a process which might be described as deep calling to deep.

That the Privy Council should ultimately knock out the teeth of the Hoani Te Heuheu decision and construe a Treaty promise as an offer that, like Don Corleone's, could not be refused, may ultimately prove Mãori Council to be a latter-day Wallis; an ultimate spur to a distinctive New Zealand jurisprudence.

George would have approved.

\section{CONCLUSION}

Each of the present number of 194 nation States values the elements of law that contribute to its distinctiveness. That is why in the end New Zealand abandoned the Privy Council. But the rapid shrinking of the globe calls for a coordinated approach to the laws governing what we have in common. That increasingly includes not only the environment but trade, communications, responses to international crime, and, as the European experience is increasingly showing, may even come to embrace international human rights. For much of its life as a New Zealand court, the Privy Council assisted the process of coordination; but its full potential was never realised. Its shortcomings included the insistence, recently modified, on sitting only in London; its cost; and the consequent inaccessibility for practical purposes for most litigants. So the cases mentioned as significant are relatively few, even though the influence of those few extends well beyond New Zealand. But no less important was failure to seize, much earlier and with more enthusiasm, the golden opportunity to use modern means of travel and communication to adapt itself to modern conditions. What might have been is seen in the invitation to Sir Robin Cooke to contribute to renaissance of the English courts which received further emphasis under the leadership of Lord Bingham. Their vision, like Mansfield's two centuries before, was of how the common law might be developed to meet current needs, both drawing on and contributing to the best jurisprudence in Europe and elsewhere.

As it is, the record of the Privy Council is largely benign. It not only, like any final appellate court, corrected errors of principle. Both in the early days and very recently it afforded protection to Māori which they had not fully received at other hands. But despite important exceptions, its failure fully to acknowledge New Zealand's independent identity, seen most importantly in its refusal during five of its final six decades to acknowledge the true legal effect to the Treaty of Waitangi, delayed the evolution of a distinctive New Zealand jurisprudence. That challenge now falls to the Supreme Court. 